\title{
Research on the Transformation and Upgrading of Physical Retailers in Internet Era
}

\author{
Juhua Xiu \\ Fuzhou University of International Studies and Trade \\ Fuzhou, China 350202
}

\begin{abstract}
With the gradual expansion of the share of ecommerce in the retail market, it has brought tremendous impact on brick-and-mortar retailers. It has released the information of closing physical store. The overall performance of physical retailers is slump, and they are facing the transformation and innovation development. In this paper, the author analyzes the status quo of the development of physical retail enterprises, and explores the impact of Internet economy on the real retail industry. And then, the author puts forward strategies for the transformation and upgrading of physical retail enterprises.
\end{abstract}

Keywords-Internet era; physical retail; transformation and upgrading

\section{INTRODUCTION}

In recent years, with the rapid development of Internet technology, consumer psychology, consumer habits and consumer behavior have shown new features. Online shopping has gradually become the main shopping method for consumers. Affected by the Internet, the development of physical retail enterprises is still sluggish. To shut up the store and the slowdown development has become common phenomenon in physical retail enterprises. The transformation and upgrading of traditional physical retail enterprises has become an inevitable trend.

\section{ANALYSIS ON THE STATUS QUO OF THE DEVELOPMENT OF PHYSICAL RETAIL ENTERPRISES}

\section{A. Online Retail Sales Continue Increasing, and Physical Retail Are Dominated [1]}

In recent years, with the rapid development of ecommerce, online retail market has maintained rapid growth According to statistics from the Ministry of Commerce, total retail sales of social consumer goods in China in 2016 reached 33.2 trillion yuan, of which the online retail market reached 5.16 trillion yuan, an increase of $26.2 \%$ over the previous year. This shows that in the Internet era, physical retail is still the main force of the retail market. And there is great market prospect. "Table I"
TABLE I. 2012-2016 ONLINE RETAIL TRANSACTIONS

\begin{tabular}{|l|l|l|l|}
\hline Year & $\begin{array}{c}\text { Online } \\
\text { retail sales } \\
\text { (trillion } \\
\text { yuan) }\end{array}$ & $\begin{array}{c}\text { Total retail sales } \\
\text { of social } \\
\text { consumer goods } \\
\text { (trillion yuan) }\end{array}$ & $\begin{array}{c}\text { The proportion of } \\
\text { online retail sales in } \\
\text { total retail sales of } \\
\text { social consumer goods }\end{array}$ \\
\hline 2012 & 1.31 & 21.0307 & $6.23 \%$ \\
\hline 2013 & 1.85 & 23.4 & $7.9 \%$ \\
\hline 2014 & 2.8 & 26.2 & $10.69 \%$ \\
\hline 2015 & 3.88 & 30.0931 & $12.9 \%$ \\
\hline 2016 & 5.16 & 33.2 & $15.5 \%$ \\
\hline \multicolumn{3}{|c|}{ a. Data source: $2012-2016$ related data collation by the Ministry of Commerce }
\end{tabular}

\section{B. The Diversified Physical Retail Industries}

In the Internet era, personalized and diversified consumer demands have become the mainstream. And it should inevitably develop the diversified operation of the retail industries. At present, domestic retail industries mainly include the forms of professional stores, specialty stores, department stores, supermarkets and convenience stores. Among them, specialty stores, convenience stores and supermarkets have become the mainstream trends in physical retail industries. Due to land prices, transportation, etc, the department stores have gradually faded out people's view. At the same time, retail mall business which is the integration of the new shopping center, physical stores and network also has rapid development.

\section{The Development of Physical Retail Is Reviving from the Downturn, and the Growth of Different Operations Is Divergent}

Since 2014, the development of physical retail has been in downturn. And a lot of stores have been shut down. By the first half of 2016, a total of 1075 major retail stores in China were closed. However, since the second half of 2016, the physical retail market has shown the trend of recovery. With the recovery of traditional retail industries, different traditional retail industries show a clear differentiation. According to the data monitored by the Ministry of Commerce, supermarkets, shopping centers and convenience stores have rapid growth, increasing by $6.7 \%, 7.4 \%$ and $7.7 \%$ respectively. The department stores and specialty stores have slow growth, increasing by $1.3 \%$ and $3.1 \%$ respectively. The growth rate of department stores is $2.1 \%$ lower than that of the previous year. The growth rate of specialty shops is $2.8 \%$ higher than that of the previous year. 


\section{The Operating Costs and Pressure of Competition of Physical Retail Enterprises Are High}

In recent years, the government has issued a series of effective measures to reduce the tax costs and financing costs of retail enterprises. However, due to the increase of labor costs, house rent and logistics costs, the pressure of operating costs of physical retail enterprises is still great [2]. At the same time, the physical retail enterprises are faced with the increasingly serious homogeneity competition situation of "one thousand stores with the same products". And the homogeneity will inevitably lead to excessive competition of market price, making the retail enterprises have a few benefits or even have no benefits.

\section{THE IMPACT OF THE INTERNET ON PHYSICAL RETAIL ENTERPRISES}

With the rapid development of e-commerce, the continuous improvement and updating of network technology and the accelerating pace of people's life, online shopping has become the main mode of shopping for the modern consumers. This has brought tremendous impact on the traditional retail business model as well as a new opportunity of the development comes.

\section{A. Changes of Consumer Demands Promote Consumer Upgrades}

In Internet era, the main consumers on the network is 80 s, 90s. And their consumer attitudes, consumer habits and consumer behaviors have undergone profound changes. They pursue personalized, scene-oriented and thematic consumption patterns. They pay attention to shopping experience, pursue the fashion and quality. They have their own understanding of the Internet economy. And consumer behaviors and consumer habits show the characteristics of diversification and decentralization. As a result, traditional marketing methods have failed to attract such consumer groups. Physical retail enterprises with price competition as the main means of competition need to constantly innovate their own products and services. And then, they can create a comfortable shopping environment for consumers and enhance consumer shopping experience.

\section{B. The Development of Network Technology would Help Marketing Optimization}

The continuous improvement and innovation of Internet technology has driven retail enterprises to make continuous strategic changes and enhance their services. Then, they may meet the needs of the pursuit of quality, intelligence, diversity and individualized products for the consumers. First, it could help retail enterprises achieve accurate marketing. In the Internet era, with the big data technology, it can help retail enterprises better tap and analyze consumer behavior characteristics, and achieve personalized recommendation of products, precise advertisement delivery and more effective humanized and differentiated services. Second, it should promote the popularity of various convenient payment methods. With the increasing security and convenience of the mobile payment technology, the traditional payment is transferring toward the mobile payment. According to the 40th "Statistical Report on the Development of Internet in China" released by China Internet Network Information Center, by June 2017, the number of mobile Internet users in China reached 724 million. The number of mobile payment users reached 502 million, and the number of mobile payment users in physical retail stores with reached 463 million [3]. Third, it provides consumers with customized products. The emergence of VR technology can effectively solve the spatial dissociation of consumers and products, reduce the information asymmetry between buyers and sellers, and increase users' sense of security and trust.

\section{The Rising E-commerce Companies Change the Competitive Landscape}

The rise of e-commerce companies has brought tremendous impact on physical retail. And it also has changed the competitive landscape of the retail market. Relying on advanced network technology and flat supply chain system, E-commerce enterprises have better operating costs, transaction efficiency and market coverage than that of physical retail enterprises. According to the data from the Ministry of Commerce, China's online retail transaction sales reached 5.16 trillion yuan in 2016. And it has become the major force driving the growth of China's retail industry. According to the data of key retail enterprises monitored by the Ministry of Commerce, the growth rate of online retail industries was $25.4 \%$, much higher than that of other traditional retail industries such as supermarkets, convenience stores and department stores.

\section{Policy Adjustments Boost the Confidence of Physical Retail Enterprises}

With the rise of e-commerce, the development of online retail, the upgrading of consumption and the rise of operating costs of the physical retail, the physical retail enterprises have encountered the difficulties in operation. And they have to shut down the stores. Then, these stores are urgent to make transformation and upgrading. In November 2016, the General Office of the State Council released "Opinions on Promoting Transformation and Innovation of Physical Retail". It has highlighted the importance of retail. It has encouraged retail innovation and on-line and off-line integration. The introduction of this favorable policy has boosted the confidence of the physical retail enterprises. It could guide the transformation and upgrading of the retail industry.

\section{THE TRANSFORMATION AND UPGRADING STRATEGY OF PHYSICAL RETAIL ENTERPRISES IN INTERNET ERA}

\section{A. To Enhance the Consumer Experience}

Physical retail enterprises should give full play to their own advantages and take the consumer as the center. Through the analysis of consumer preferences, interpersonal relationships, consumer stratification, we should develop the fine operation with differentiation [4]. In response to consumer needs such as rejuvenation, personalization, diversification and quality, we should further promote 
socialization and scene-orientated consumption models to enhance the consumer experience. Physical retail enterprises can collaborate with major social platforms such as QQ, WeChat and Weibo. They could provide services such as branding promotion, affiliate marketing, sales and payment. With the communication with consumers, it could enhance consumers' social psychological dependence on the brand. And then, it would achieve the effect of word-mouth publicity. At the same time, we can create a good shopping environment by combining with the design of physical scenes, and open up scenes, products, services and experiences. Then, we can provide continuous services value to attract customers and retain customers.

\section{B. To Innovative Diversified Profit Model}

Physical retail enterprises should penetrate the Internet thinking into the value chain of the whole enterprise, combine with own advantages, strengthen the integration with the e-commerce channels, expand the product line, reduce the shopping links, and explore diversified profit models. On the one hand, physical retail enterprises can provide marketing cooperation services such as store advertisement, terminal service personnel and free internet resources for brand partners and businessmen by building a diversified marketing and promotion platform with high cost performance and high coverage. On the other hand, it can utilize the advantages of warehousing and transportation to broaden the scope of business services and provide lowercost logistics and distribution services for the electricity supplier enterprises. At the same time, the unified physical retail stores' supporting services include real-time delivery, nearest return and post-sale maintenance [5].

\section{To Construct a New Pattern of Online and Offline Integration Dominated by Physical Retail}

At present, the growth of e-commerce business slows down. The retail profit of enterprises plunges. And we have to integrate the respective advantages of physical retail channels and e-commerce channels. And then, it would achieve the integration of on-line and off-line businesses. Physical retail has its own advantages in terms of product experience, brand service and instant consumption. And the e-commerce channels have advantages in terms of price, time-space constraints and information transparency. It should complement and integrate the advantages of both physical retail channels and e-commerce channels. It is an inevitable choice to conform to the increasingly diversified and individualized needs of consumers.

We should construct the online and offline integration dominated by physical retail. First, it should take consumer as the center, strengthen the deep integration with the ecommerce business, form the overall channel model of "online orders, offline pickup and delivery, the shopping in physical stores + mobile payment", and open membership system, transaction payment system and product system. Second, we should enhance the community operations capabilities of physical retail enterprises, and build an application platform with Tencent, WeChat, WeiBo and other social platforms. And then, the consumers could have information on goods, preferences and services in physical stores online. Also, we can find the target consumer groups through WeChat, QQ and other social chat software. With word-mouth publicity, it would increase consumer source and consumer purchases. Third, it should digitize the store experience. With the development of big data technology, we can catch and categorize the information of each product that consumers search on the Internet. Then, we could get the behavioral preferences of consumers. Physical retail enterprises can push this product information to the search engine webs used by each consumer through the advertising, sending red envelopes, etc. on the internet platform. With the personalized recommendation, it would improve customer stickiness. At the same time, we could install intelligent Internet applications in physical stores, such as providing QR code scanning, software account application, shopping evaluation and feedback platform, message pushing and logistics services. The convenient purchase make consumers have different shopping experiences at offline physical stores, and enhance consumer satisfaction.

\section{To Reconstruct Intelligent and Efficient Supply Chain System}

Physical retail enterprises have weak control over the supply chain. The lagging transmission of logistics information would lead to the mismatch between supply and demand, high inventory of enterprises and low turnover rate. We should reconstruct the supply chain system with consumer as the center and timely information transmission. It should further enhance the efficiency of the integration of production, channel and consumer. And it is an important measure to achieve the transformation and upgrading of the retail industry. First, it should promote the visualization of the supply chain. E-tagging can be used in the operation of the physical retail enterprises to realize online and offline data synchronization. The data of SKU, inventory, price and promotion are fully used to facilitate the visualization of the supply chain. And then, it would realize the needs of consumers, stores or network inventory, sales trends, logistics information, visual display of the origin of information. Also, it should improve the efficiency of information transmission. Second, it should promote the precision services of supply chain. In the Internet era, it emphasizes consumer experience. The inefficient service of high stock-out rate and order delivery are important factors affecting the consumer experience. To achieve accurate service, we must make full use of data analysis to integrate the entire supply chain and data generated from B2B platform. We should timely analyze and process consumer behavior characteristics, capture the needs of consumers and make accurate forecasts, and provide the help with the development of explosives analysis, marketing forecasts and branding strategy. The inventory will be reduced at the minimum. Even, it would have no inventory. Also, it should improve the accuracy of the operation and enhance consumer satisfaction. 


\section{CONCLUSION}

The strong rise of e-commerce has brought tremendous impact on the physical retail enterprises. With the increase of operating costs and the intensified market competition, the physical retail enterprises have experienced a decline in revenue and a sharp drop in profits. Even, they have a loss. The development of physical retail enterprises are in troubles. They must have the transformation and upgrading. In order to better adapt to this trend, physical retail enterprises should propel the concept of taking consumer as the center. They should further enhance the consumer experience. They should explore innovative and diversified profit models, enhance online and offline integration dominated by physical retail enterprises. Also, they should reconstruct smart and efficient supply chain system.

\section{REFERENCES}

[1] Wu Yajun. Analysis on the recovery of traditional retail business in "Internet plus" era [J]. Technical Economy and Management Science, 2017 (26): 243

[2] China e-Business Research Center. The main modes and countermeasures of the integration development of e-commerce channel and physical retail channel [EB / OL]. (2017-03-30). http: //www.100ec.cn

[3] China Internet Network Information Center. The 40th "Statistical Report on the Development of Internet in China" [R], 2017-07.

[4] Shi Hualing. Innovative development strategy of China's physical retail enterprises under the background of "Internet plus" [J]. Business Management, 2017 (17): 99-101

[5] Lei Cuiling. Transformation and innovation of physical retail industry based on the development of Internet economic [J]. Journal of Commercial Economics, 2016 (03): 22-24 